\title{
The McLean Report: legitimising Victoria's new assimilationism
}

\author{
Corinne Manning
}

In 1955, the newly elected Victorian Premier, Henry Bolte, appointed retired stipendiary magistrate, Charles McLean, to conduct an inquiry into the operation of Victoria's Aborigines Act 1928. ${ }^{1}$ The Liberal government expected McLean's findings to reflect the assimilationist trend which was being advocated by other Australian States and Territories. Subsequently, the inquiry's five terms of reference ensured that McLean broadened Victoria's definition of Aboriginality to include large numbers of 'mixed descent' Aboriginal people, and that he formulated methods by which Aboriginal people could be assimilated into Anglo-Australian society. In general, government directives controlled the scope of the McLean Inquiry and meant that in many respects McLean served as a puppet for the Victorian government. However, the manner in which McLean sometimes deviated from these directives indicates that he was not merely a government mouthpiece.

In order to understand the establishment of the McLean Inquiry, it is necessary to consider the national and international pressures exerted on both Labor and Liberal governments in Victoria in relation to Aboriginal welfare policies. Assimilation first emerged in the Aboriginal policy of Victoria in 1886, although northern colonial governments continued to follow the path of segregation for decades. ${ }^{2}$ According to

1. Since the introduction of the Aborigines Act 1886, Victoria's Aboriginal welfare policies had been a mixture of assimilationist and segregationist ideals. The 1886 Act deemed that government reserves were to be retained for Aborigines who were 'full bloods', 'half-castes' over 34 and their 'half-caste' wives and children. The newly created Board for the Protection of Aborigines, was able to grant licences to 'half-castes' under the age of 34 to reside at the reserves. The Governor also retained the right to regulate for the care and management of 'half-castes', the apprenticeship of children and the removal of orphans to institutions. The Aborigines Act 1928 was similar to its predecessor, but with a broader definition of Aboriginality. The new categorisation included 'half-castes' who lived or associated with 'full blooded' Aborigines; 'half-caste' children of those deemed to be Aboriginal, or unable to earn a living, or who held a special licence from the Board to reside on its reserves. It also included 'half-castes' who were 34 when the 1886 Act was implemented. This definition of Aboriginality excluded the majority of Aboriginal Victorians who were classified as 'mixed-descent'. These people were forced to live in the general community with little or no access to government support. Both the 1886 and 1928 Acts reinforced the widely held idea that the only 'real' Aborigines were the 'full bloods'. See Broome 1995:139-140; Rowley 1971: 43-44.

2. Christie 1979: 200-201. 
Richard Broome, the Aborigines Act 1886 was a blend of segregationist and assimilationist thinking. Under this Act, protectionist ideals were applied to the treatment of 'fullbloods' and 'half-castes' over the age of 34 and their wives and children. People who belonged to these categories were eligible to be supported by government funding and were allowed to reside at Aboriginal mission stations. 'Half-castes' under the age of 34, except for those licensed to remain at the Aboriginal missions, were required to assimilate into the general community, with limited support from the Aborigines Protection Board. ${ }^{3}$ This combination of protectionist and assimilationist idealism dominated Victoria's Aboriginal welfare policies from 1886.

Prior to World War II, Aboriginal welfare policies were often based on notions of Social Darwinism which many people, such as Herbert Spencer, applied to the development of human societies. ${ }^{4}$ In simplified terms, Social Darwinism used 'survival of the fittest' to explain the dominance of European colonisers over the 'weaker' black races. ${ }^{5}$ After the outbreak of World War II, when the Nazi régime became Australia's enemy, 'race' became a dirty word and Australia devised a new policy for Aboriginal Australians based on the equality of races. ${ }^{6}$ According to sociologist Colin Tatz, assimilation was a policy that considered all men and women to be born equal in their natural and human rights. ${ }^{7}$ This philosophy appeared to be the antithesis to Nazism and, in theory, it placed Aboriginal Australians on equal terms with Anglo-Australians.

Assimilation was adopted as policy by the Federal government in the 1937 Native Welfare Conference. However its implementation was delayed by the outbreak of World War II and was not revived until Paul Hasluck was appointed as the Federal Minister for Territories in May 1951. In September 1951, Hasluck urged government delegates at the Australian Native Welfare Conference to revitalise the 1937 decision to develop and implement assimilation-style Aboriginal welfare policies. ${ }^{8}$ All conference participants agreed with Hasluck's proposal and assimilation became the key element of many Aboriginal welfare policies in the 1950s and 1960s. Hasluck's vision of assimilation differed from the more restrictive 1937 definition in that it included 'all persons of aboriginal blood or mixed-blood'. ${ }^{9}$ This definition assumed that all Aboriginal people were willing to forego their heritage and adopt the living standards and culture of Anglo-Australian society. Hasluck was a humanitarian person, genuinely concerned with improving the lives of Aboriginal Australians. However, his model of assimilation was racist, as Aboriginal people were expected to shun their Aboriginal culture in return for the better material living conditions of the dominant community.

The unanimous endorsement received from participants of the 1951 Native Welfare Conference may have been due to increased political concerns about Australia's human rights image overseas. The historian Susan Taffe states that in the 1950s and 1960s Australia's treatment of its Aboriginal people was scrutinised by members of the

3. Broome 1995: 139.

See Cowlishaw 1999; McGregor 1997; Markus 1990.

Broome 1994: 92.

Hasluck 1988: 6.

Tatz 1990: 247.

8. At this time Aboriginal welfare was the responsibility of State governments with the federal government having jurisdiction only over the Northern Territory.

9. Hasluck 1953: 56-57. 
United Nations during its investigations of issues concerning colonialism and its negative effects on indigenous cultures. ${ }^{10}$ In June 1950, Hasluck stated in federal parliament: 'When we enter international discussions today in defence of human rights, our very words are mocked by the thousands of degraded and depressed people on rubbish heaps throughout the continent'. ${ }^{11}$ In 1951, during a House of Representatives debate on Aboriginal affairs, Labor MP Tom Burke supported this notion: 'We must not only satisfy our conscience in this respect [improving the living conditions of Australian Aboriginal people] but also remember that the eyes of the world will watch critically the work that we do for the welfare of native peoples' ${ }^{12}$ The national Native Welfare Conferences provided a forum in which human rights issues were addressed and provisions made to improve Australia's international reputation.

In the early 1950s, the Victorian government's official policy precluded the State's Aboriginal residents from taking part in the revitalised assimilation program because it considered the issue solved. Although assimilation had been evident in many of Victoria's Acts concerning Aboriginal welfare, official thinking in Victoria determined that 'mixed descent' Aboriginal people who lived in association with people of European descent, or in the manner of Europeans, were not in fact 'Aborigines'. This definition of 'Aborigine' excluded the vast majority of Aboriginal people who lived in Victoria at this time, because they were of so-called 'mixed descent' and resided near or within European communities. Accordingly, the Victorian government did not have a minister for Aboriginal affairs, nor a department concerned solely with Aboriginal welfare. The 1937 and 1951 assimilationist doctrines were primarily focused upon the assimilation of 'mixed descent' Aboriginal people into the dominant community. The Victorian government's unwillingness to broaden its definition of Aboriginality beyond genealogically determined 'full' or 'half-caste' classificatory status meant that Victoria was not a participant in the assimilationist movement of this time.

The Victorian government's decision not to participate in the Native Welfare Conferences and the assimilation program was criticised by some Victorian parliamentarians and community groups. In September 1951, Ernest Morton, a State Labor parliamentarian, demanded an official explanation as to the government's nonattendance at the Native Welfare Conference. He stated that the living conditions of many Victorian Aboriginal people were a disgrace to Christianity and that political action was necessary to rectify this situation. ${ }^{13}$ Community organisations such as the Victorian Aboriginal Group, the Women's International League for Peace and Freedom and Apex supported Morton's viewpoint. The Chairman of the Board for the Protection of Aborigines (Victoria) and Chief Secretary of the Labor Party, Keith Dodgshun, replied that the situation of Victorian Aboriginal people was different from that of other States. He claimed that successive State governments had done more for the native inhabitants than had any other State, which resulted in Victorian Aboriginal people being 'civilised' and considered by Anglo-Australians as equal citizens. Dodgshun believed that the key motive for Victoria's invitation to the conference was the procure-

10. Taffe 1995: 154-157.

11. Argus, 9 June 1950.

12. Commonwealth of Australia Parliamentary Debates (CPD), vol. 213 (1951): 172.

13. Victorian Parliamentary Debates (VPD), vol. 236 (1950-1951): 4281. 
ment of money for the other States' Aboriginal programs. ${ }^{14}$ When the second Native Welfare Conference was held in 1952, Victoria again declined to send any delegates. Dodgshun reiterated the government's position and interpreted Aboriginality more narrowly than formerly by arguing that only nine 'full-blooded Aborigines' resided in Victoria and that they were 'well housed' and 'looked after' on the Lake Tyers mission. ${ }^{15}$ Morton challenged this remark by referring to the appalling conditions under which many fringe-dwelling, 'mixed descent' Aboriginal people lived on the Goulburn River at Shepparton. Dodgshun responded, 'They are not aborigines ... There are only nine full blooded aborigines in Victoria; the others are quadroons, half-castes and so forth'. ${ }^{16}$ This statement reinforced the government's narrow definition of Aboriginality and indicated that the Victorian government used selective biological criteria to determine Aboriginality.

During the 1940s and 1950s, public fear increased amongst Victoria's non-Aboriginal residents concerning growing numbers of Aboriginal people living as fringedwellers. Economic prosperity in the 1950s led to an increased standard of living for most Australians, creating a stark contrast between the prosperity of many Anglo-Australians and the slum conditions in which many fringe-dwellers lived. ${ }^{17}$ Phillip Boas, a welfare officer employed by the Victorian government in the 1960s, states that fringedwelling in the 1940s and 50s was perceived by Anglo-Australians to be an affront to 'decent standards' and a possible threat to law and order. ${ }^{18}$ This was evident in many newspaper articles of this period. For example, in 1954 the Argus published an article which referred to Aboriginal fringe camps as a 'social cancer'. It argued that local residents considered the fringe camps to be 'wicked' and demanded government intervention to remedy the situation. ${ }^{19}$ Public pressure was one factor which contributed to the government's decision to hold an inquiry.

Growing discontent in the Victorian community about the management of Aboriginal affairs by the Board for the Protection of Aborigines led to Victoria's reevaluation of its Aboriginal welfare policy. In his study of Victorian Aboriginal policies, Mark Harris argues that internal conflict and division amongst the Board's members resulted in government and public concern about its operation. ${ }^{20}$ In 1952, the Board's Aboriginal representative, Shadrach James, stated, 'The administrative work of the Aborigines' Protection Board had finished, and it should now cease functioning' ${ }^{21} \mathrm{He}$ argued that the Board had been established to protect the interest of Victoria's 'fullblooded' Aboriginal people, but only three 'full-bloods' resided in the State, therefore the Board administered to approximately one hundred and twenty 'mixed descent' Aboriginal people in order to ensure its continued operation. ${ }^{22}$ Harris believes that constant press reports detailing the harsh living conditions of most of Victoria's Aboriginal

14. VPD vol. 236 (1950-1951): 4282.

15. VPD vol. 236 (1950-1951): 4282; VPD vol. 240 (1951-1952): 2212.

16. VPD vol. 240 (1951-1952): 2212.

17. Brown 1995: 101.

18. Boas 1972: 52.

19. Argus, 21 August 1954.

20. Harris 1988: 40.

21. Argus, 28 May 1952.

22. Argus, 28 May 1952. 
people were perceived by the general public to reflect a failure of the Board to care effectively for those in its charge. ${ }^{23}$ In December 1955, Arthur Rylah, Chief Secretary and Chairman of the Board, announced to a meeting that:

On his recommendation, Cabinet had decided to appoint a Board of Inquiry to make a factual survey of the conditions under which aboriginal people are living in the state, investigate the policy being followed in respect of the Lake Tyers station and advise the Government as to any changes in system of administration considered to be necessary or desirable for the better care of people of Aboriginal blood. $^{24}$

Premier Bolte appointed Charles McLean to undertake this review and to recommend legislative reform. ${ }^{25}$ McLean was an experienced investigator, and had completed inquiries for the West Australian and Victorian governments. These inquiries were concerned with the sport of trotting, gambling, and the escape of five prisoners from Pentridge prison. ${ }^{26}$

McLean's reputation in the public sphere as a conservative Anglophile led to his appointment as chief investigator. He was born into a middle class, Anglo-Saxon family in 1889. His father was a head teacher who encouraged McLean to utilise his intellectual abilities to advance his social position. ${ }^{27}$ Consequently, McLean received a private school education at Grenville College, an independent, Protestant school situated near Ballarat. The school, also attended by future Prime Minister Robert Menzies, insisted on high academic standards and encouraged its students to identify their privileged position in society with their school. The school's philosophy stressed that personal excellence was the result of hard work, discipline, and loyalty to British social traditions. ${ }^{28}$ McLean embraced these ideals and they were foremost in his professional life as a public servant.

McLean's conscientious career in the public service culminated in his appointment as a magistrate in 1930. According to a colleague, William Cuthill, McLean was renowned for his relentless work ethic and unwavering dedication to the law. ${ }^{29}$ On his retirement in 1954, many public officials praised him for being conscientious, noble and merciful. ${ }^{30}$ However, not everybody agreed with this image. A report written by Darrell Symmons in the Sun News Pictorial berated McLean for his stern nature. He wrote, 'Mr McLean's term of office has been marked by a sense of duty so stern that I was mentally stunned when I first began to attend the City Court ... His magistracy was a strict adherence to the letter of the law ... This was most oppressive, in my opinion, in cases of vagrancy. ${ }^{31}$ McLean was aware of his harsh reputation. He stated to Cuthill, '[I was] a bastard in the office ... I felt that I had a mission there.' ${ }^{32}$

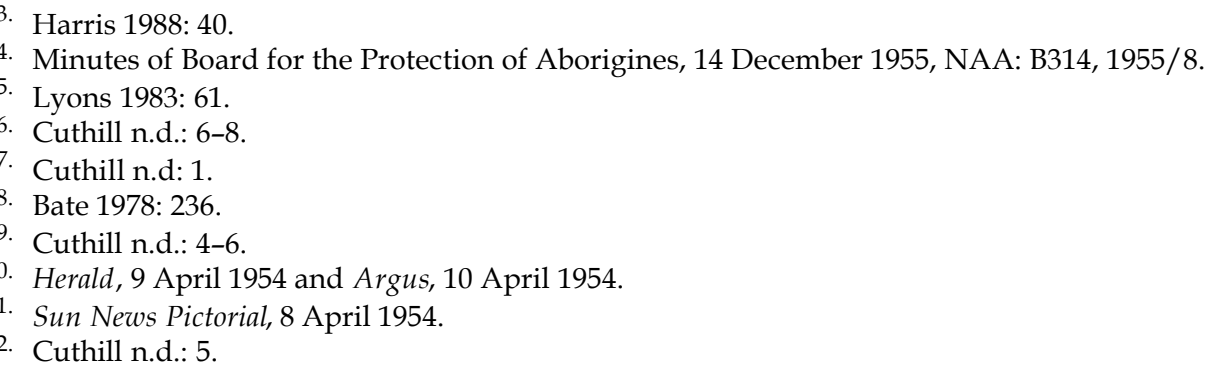


In many respects, McLean was a self-made man who succeeded in his chosen career through adhering to the dominant models of social behaviour, which included hard work and dedication to his employer. Vagrants, on the other hand, were categorised by the law as idle, disorderly, nomadic people who 'sponged' off society and failed to make a positive contribution to the dominant community. Aboriginal fringe camps and fringe-dwellers were often associated with vagrancy, due to the predominantly seasonal employment available to Aboriginal people, and the lack of adequate permanent housing for their families. Consequently, vagrants and Aboriginal fringedwellers were often considered to be a public 'menace'.

By appointing a Chief Investigator known for his harsh views towards vagrants, the Victorian Government could pre-determine many of McLean's findings. McLean's deference to British-derived law and British-Australian culture promised that his recommendations would adhere to the dominant doctrine of the day: the assimilation of outsiders into the mainstream. The Liberal government relied on the McLean Report to deliver them the justification for the introduction of new assimilationist legislation in the area of Aboriginal welfare.

In setting up the inquiry, the government developed five terms of reference which required McLean to investigate the living standards of Aboriginal people on reserves and in fringe camps, to define Aboriginality and to offer solutions to Victoria's 'Aboriginal problem'. In many respects, the McLean Inquiry was similar to the 1937 New South Wales Parliamentary Inquiry into the administration of Aboriginal Affairs in that State. Both investigations were to determine the potential for Aboriginal people to be socially re-engineered to reflect the values and lifestyle of Anglo-Australians.

McLean's first term of reference was to establish the number, distribution and living conditions of people deemed to be at least one-quarter Aboriginal, who were capable of working or who were regularly employed. ${ }^{33}$ This definition of Aboriginality differed from previous models which had determined that the only 'real Aborigines' were 'full-bloods' or those 'half-castes' who associated with them. ${ }^{34}$ In McLean's handwritten notes concerning the definition of Aboriginality that he intended to include in his final report, he listed two definitions of Aboriginality. The first, which had a pencil line struck through it, stated that 'an Aborigine was a person whose parents were both full-blooded Aborigines'. The second definition, which he included in his final report, stated that anyone with an 'admixture' of Aboriginal blood was to be considered an Aborigine. ${ }^{35}$ McLean used the second broad definition in his investigation of Victoria's Aboriginal population. This indicated McLean's willingness to deviate from the government directive, which only included Aboriginal people who were at least 'quartercaste', in itself a liberalisation of earlier definitions. In his report McLean declared that Victoria had a population of 1346 Aboriginal people. He claimed that 131 Aboriginal people resided at Lake Tyers station, 159 in the metropolitan area and the remainder were scattered throughout regional districts. ${ }^{36}$ These statistics were obtained by

33. Charles McLean, VPP: 3, Paper no. 18, 1957, vol. 2, 'Report upon the operation of the Aborigines Act 1928 and the Regulations and orders made thereunder', hereafter referred to as the McLean Report.

34. VPD, vol. 240 (1951-1952): 2212

35. McLean Notes, NAA: B408, 1956/3. 
collating population information forwarded by the police and 'other sources', such as the Board for the Protection of Aborigines. McLean's data negated the earlier claim by the government that Victoria only had nine Aboriginal people. However, he was aware that insufficient population records meant that his calculations were also inaccurate. He stated:

these figures, though as accurate as can be expected, are not statistically exact ... The principal inaccuracy arises from the difficulty of assessing the percentage of aboriginal blood in many cases. Over the succeeding generations ... there has been such a high degree of miscegenation, and of sexual promiscuity on the part of aboriginal women and white men (and some coloured men of other nationalities), that such an assessment could, at best, be only approximate. Personal observation on my visits to aboriginal communities indicated that, included in the figures given, were some who were fairly obviously of less than one-fourth aboriginal blood ... Though the figures given are subject to that qualification, this is perhaps not important, since they present the same problem, and are equally relevant to the purpose of this inquiry. ${ }^{37}$

McLean's comments indicate the degree to which Aboriginality was often defined by physical characteristics, particularly in terms of colour. As the anthropologist Myrna Tonkinson has argued, this form of categorisation reflected racist notions that biological factors determined cultural characteristics. ${ }^{38}$

The McLean Report reiterated claims that Aboriginal fringe camps were a danger to Australian society. McLean visited many Aboriginal fringe communities, over a one year period, accompanied by local police and welfare officers. The fringe camps he visited included those located at Mooroopna, Framlingham, Dimboola, Antwerp, and in the Orbost district. ${ }^{39}$ The image of camp life was sometimes distorted by local efforts to 'clean up' for McLean's impending visit. This was evident when McLean visited Shepparton and Mooroopna in April 1956. The official report compiled from his visit stated that rubbish was bulldozed away from the Daish's paddock camp ${ }^{40}$ and that 1200 wine bottles had been removed in preparation for McLean's investigations. ${ }^{41}$ McLean spoke with very few fringe-dwelling residents and inspections were often planned for weekdays and during the early afternoon, which meant that many of the Aboriginal people were absent due to work commitments. In addition, it was noted in the official visitation report that many Aboriginal people 'were away, word having got around that "the man was coming"'. ${ }^{42}$ The reluctance of many fringe-dwellers to contribute to McLean's Inquiry reflected the prevailing fear of government authorities, a legacy of decades of Protection Board surveillance and removal of children. Unfortunately, this nonappearance may have also contributed to the omission from McLean's final report of Aboriginal opinions, particularly concerning the positive aspects of fringe

36. McLean Report: 6 .

37. McLean Report: 6.

38. Tonkinson 1990: 201-202.

39. McLean Report: 3.

40. 'Daish's paddock' was the named used to refer to an Aboriginal fringe camp situated next to the town rubbish tip in Mooroopna.

41. Official Report of the McLean Inquiry's visits to Shepparton and Mooroopna, 12-13 April 1956, NAA: B408, 1956/1.

42. McLean Inquiry's visits to Shepparton and Mooroopna, 12-13 April 1956, NAA: B408, 1956/1. 
communities. Instead, the local police, community organisations and government welfare authorities provided most of the information concerning the fringe camps.

In his report, McLean described a typical fringe camp:

'humpies' are mostly constructed of old timber, flattened kerosene tins, and hessian, usually with some kind of partition to separate bedroom from living room. They are not weatherproof, have earthen floors, very primitive cooking arrangements, and no laundry or bathing facilities except the river, from which all water is drawn by buckets, and carted for distances up to half a mile. There are few sanitary conveniences, with all kinds of containers used as pans. The contents are buried close handy in shallow holes, or sometimes just tipped on the ground. ${ }^{43}$

McLean believed that Aboriginal fringe camps were a social threat and a source of shame for Australian people. He stated that fringe camps were 'a grave danger to health, both from water pollution and from general infection.' McLean reported that most of the huts were overcrowded and 'very dirty'. He also claimed that although some of the fringe-dwellers were 'decent-living people', excessive drinking often led to violence, immorality and gambling. McLean referred to the Aboriginal children as dirty, undernourished and neglected. He argued that the majority of Victoria's Aboriginal people lived in these harsh environments and the abolition of these conditions was imperative if assimilation was to occur. ${ }^{44}$ McLean's contempt for the fringe-dwelling lifestyle meant that he failed to acknowledge that, in spite of the harsh living conditions, fringe camps often empowered their residents. Many historians and anthropologists, such as Charles Rowley and Jeff Collmann, have argued that Aboriginal people preferred to live in fringe camps because they offered a means of escaping government authorities, whilst enabling residents to maintain traditional kinship ties in a community of like-minded people. ${ }^{45}$ McLean presented a view from the outside, looking at conditions from a conservative and materialist perspective. He did not recognise or value the cultural and kinship customs being practised, as his main focus was on assimilation, which assumed that the Indigenous culture would be sublimated to the dominant settler culture.

The second term of reference of the McLean Inquiry was to ascertain the capacity of Aboriginal people to live and maintain themselves and their families according to the general standards of the Victorian community. ${ }^{46}$ McLean considered both the physical and mental abilities of Aboriginal people. In terms of physical qualifications, McLean believed that Aboriginal people had 'proved' themselves to be equal to their AngloAustralian counterparts. He supported this claim by referring to the success of Aboriginal people in the sporting arena, particularly in football and boxing. ${ }^{47}$ McLean's assertions correlated with later studies concerning Aboriginal people's accomplishments in the sporting field. In his study of Aboriginal boxers between 1930 and 1979, Richard Broome argues that one of the main attractions of sport was the opportunity for Aboriginal people to escape the racism inherent in the general community. ${ }^{48}$ He states:

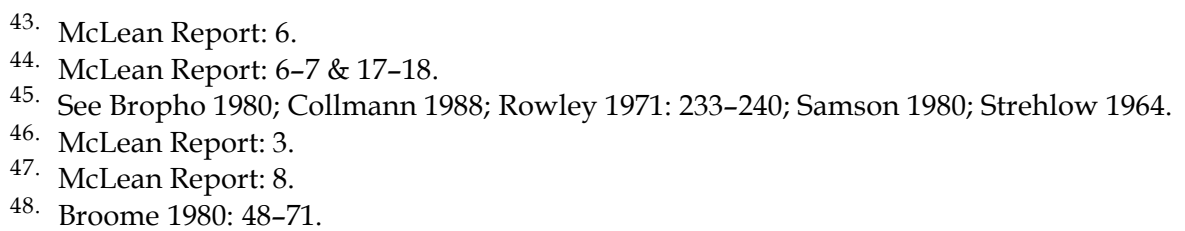


'In the ring, or on the football ground and tennis court, black and white had equal opportunities to reveal their capabilities. ${ }^{49}$ Indeed, the Aboriginal one per cent of the population produced fifteen per cent of national professional boxing champions over fifty years. The sporting arena provided some Aboriginal people with the opportunity to compete as equals against their Anglo-Australian counterparts. However, in mainstream Australian society Aboriginal people were often treated as second class citizens.

McLean noted that many Aboriginal people were considered to be excellent physical labourers within industries such as fruit and vegetable picking. ${ }^{50}$ From the 1930 s to the 1950s the expansion of the fruit growing industries along the Murray ensured that Aboriginal people were supplied with regular seasonal employment. ${ }^{51}$ A strong work ethic displayed by some Aboriginal people contributed to their positive reputation amongst some of the rural employers as reliable and hard-working seasonal labourers. Donald Howe, a Mooroopna farmer, stated that local farmers often considered Aboriginal people to be more reliable workers than their Anglo-Australian counterparts. He argued that most Aboriginal labourers were committed to working throughout the entire fruit and vegetable picking season, whereas many other employees often worked until they earned enough money to move on. ${ }^{52}$

McLean's acknowledgment of Aboriginal physical abilities served to reinforce the assimilationist idea that Aboriginal people were physically capable of living like AngloAustralians. When highlighting the propensity for many Aboriginal people to suffer from respiratory and other specific physical disorders, he stated that these illnesses were a product of poor living conditions and could be easily remedied through the provision of better standards of housing and education. ${ }^{53}$

In order to provide a better standard of living, the government wished to investigate the degree to which Aboriginal people were 'mentally capable' of living as AngloAustralians. In his report, McLean stated that 'most authorities now agree that there is no innate racial inferiority of intelligence in the aborigine. ${ }^{54}$ In an effort to make his own evaluation, he sought information from Health, Mental Hygiene and Education Departmental officers, school inspectors and head teachers who taught in schools with Aboriginal pupils. His findings argued that:

the great majority of the people of aboriginal blood do attain maturity in age without having acquired the mental equipment which accompanies the ordinary standard of education. I think the view must be accepted that this is rather the product of existing conditions than of any strictly biological disability, and that, basically, they have the capacity to live and maintain themselves and their families according to the general standards of the Victorian community. ${ }^{55}$

9. Broome 1994: 157.

50. McLean Report: 8 .

51. Rowley 1971: 179-180.

52. McLean Inquiry's visits to Shepparton and Mooroopna, 12-13 April 1956, NAA: B408, 1956/1.

53. McLean Report: 8.

54. McLean Report: 8.

55. McLean Report: 9. 
McLean rejected the viewpoint of many people that Aboriginal children, although able to process simple tasks, were unable to progress beyond the fourth or fifth grades. McLean argued that the scholastic backwardness of many Aboriginal children was due to insufficient encouragement to learn from parents and teachers, and irregular school attendance caused by their parents' seasonal employment, rather than any inherent mental deficiency. ${ }^{56}$ McLean's focus was narrow in determining the reasons as to why many Aboriginal children failed to reach the same education levels as their Anglo counterparts. McLean could have added that many Aboriginal children in fringe camps had difficulty accessing school, experienced racism whilst there, and thus found it more congenial to enter the workforce at an early age. However, his opinions concerning 'mental capacity' served to 'officially' negate Darwinian beliefs that Aboriginal people were innately intellectually inferior to other Australians.

Although McLean dismissed biology as a determining factor of mental capacity, his comments on the 'blood' composition of Victoria's Aboriginal people euphemistically reflected the dominant racial and class discourses. He stated:

As to their [Aboriginal people's] mental capacity, most authorities now agree that there is no innate racial inferiority of intelligence in the aborigine. In any case, there is a preponderance of white blood among those in Victoria, though some degree of degeneration from the general average of the white race might perhaps be expected from the fact that much of the white parentage has had its origin in the association of 'sub-standard' whites, in an atmosphere of drink and degradation, with aboriginal women in their camps. ${ }^{57}$

In an effort to publicly denounce racial ideas, McLean paradoxically exposed his belief in the effect of biology on people's mental capacities.

Racism was still rife throughout Australia during the 1950s and Darwinist ideals infiltrated the new rhetoric of assimilation. Historian Andrew Markus states that in the 1930s many important administrators and politicians concerned with Aboriginal welfare and policy, such as AP Elkin and AO Neville, used Darwinist language and ideals in their discussions related to assimilation. ${ }^{58}$ For example, Neville believed that the biological assimilation of mixed-descent Aboriginal people was possible due to the fact that they partly 'sprang from the same stock as we did ourselves'. ${ }^{59}$ This type of language was evident when McLean claimed that 'a positive endeavour by some [AngloAustralian] supervisory authority [needed to be made] to counteract the disadvantages, inherent and other, which seem peculiar to them [Aboriginal people]' ${ }^{60}$

The ethnocentric language of his report indicated McLean's struggle to replace his old racial ideology with the new assimilation doctrine. For example, McLean argued that many Aboriginal people were unable to fend for themselves in the dominant Australian community because of factors emanating from a 'racial origin'. ${ }^{61}$ McLean's rhetoric was often concerned with a discussion of the differences between the "two

\footnotetext{
56. McLean Report: 9.

57. McLean Report: 8.

58. Markus 1982: 85-102.

59. Markus 1982: 97.

60. McLean Report: 15, my emphasis.

61. McLean Report: 8.
} 
races': black and white Australians. He repeatedly referred to the negative aspects of traditional Aboriginal culture and used the term the 'black race', which he considered hindered the progression of many Aboriginal people in the dominant community. He stated: 'Some of the characteristics militating against [Aboriginal people's] economic progress ... have a racial or a traditional origin. ${ }^{62}$ McLean also criticised 'sub-standard white people' for their 'immoral' role in parenting 'mixed descent' Aboriginal people.

McLean's negative assumptions about Aboriginal culture may also indicate that he subscribed to certain notions of primitivism. According to Nicholas Brown, during the 1950s many Anglo-Australians espoused the view that Aboriginal people's transition from primitivism to modernity would result in an improvement in their standard of living and their subsequent acceptance as equal citizens. ${ }^{63}$ Assimilation was put forward by many politicians, community welfare groups and Aboriginal activists as the method by which equality would be achieved. McLean appeared to support this idea. He stated that Victorian Aboriginal people needed to forego their 'primitive habits' and conform to the social standards inherent in modern Australia. ${ }^{64}$ McLean believed that Aboriginal beliefs pertaining to property ownership were indicative of their 'backwardness' and a throwback to their 'tribal days'. He claimed that Aboriginal principles associated with property ownership and 'walkabout' resulted in the degraded living standards of many Aboriginal families. ${ }^{65}$ Rather than adhering to laissez-faire notions concerning the right of an individual to own and preside over a particular piece of property, Aboriginal people believed in the communal use of land with no individual property rights. McLean criticised this practice. He argued that this system of 'sharing' resulted in 'immorality' and hardship for many Aboriginal people. To support his claim he cited the case of a widow in Mooroopna, who received $£ 2000$ compensation for the death of her husband. He stated that due to her kinship responsibilities, the money was spent over three months, with the assistance of Aboriginal kin, on 'frivolous' items such as alcohol and taxi fares. He argued that the result of her adherence to Aboriginal values was the removal of her ten children by the Children's Welfare Department. ${ }^{66}$ McLean wanted to put an end to these 'primitive' customs which he believed militated against Aboriginal people's absorption into the modern Australian community.

McLean believed that Aboriginal children were victims of their parents' adherence to traditional practices and their current lifestyle as fringe-dwellers. He wrote that children were 'infected' during their formative years by the negative influences of Aboriginal adults which led to their poor education and resistance to participating in Australian society. ${ }^{67}$ In order to rectify this situation, he proposed greater surveillance by welfare authorities and improved education standards. However Euphemia Mullett, an Aboriginal woman who lived at a fringe camp known as Jackson's Track during this era, countered McLean's argument. She stated that all of her children regularly attended the local school and were considered to be good students. ${ }^{68}$ Mullett believed

62. McLean Report: 10.

63. Brown 1995: 53-55.

64. McLean Report: 9-10.

65. McLean Report: 10.

66. McLean Report: 9-10.

67. McLean Report: 10-11.

68. Jackomos and Fowell 1991: 18; Landon and Tonkin 1999: 64-70. 
that her children benefited from a combination of Aboriginal and European styles of education. ${ }^{69}$ McLean failed to explore the positive aspects of Aboriginal education and culture. Instead, he espoused the government's viewpoint that assimilation was necessary in order to eradicate destructive Aboriginal social systems, particularly fringe camps.

McLean claimed that the only barrier to assimilation was that posed by AngloAustralians: their belief in their superiority over Aboriginal people. However, he insisted that racial prejudice was primarily related to employment issues and rarely existed in the general community. ${ }^{70}$ This statement disclosed his unwillingness to acknowledge the colour bar which existed in many Australian communities. At the launch of Apex's 1956 Aboriginal sponsorship scheme, Arthur Holden, the director of the new program, challenged the audience to 'take a look around you, if you do not believe that the colour bar exists here in Australia'. ${ }^{71}$ Written submissions made to the McLean Inquiry blamed racism for the current social situation of Aboriginal people. One of these submissions was a letter written by Margaret and Percy Holmes, two concerned private citizens from Seymour. They wrote:

The real problem of the Aborigines is the prejudice in the minds of white people against the mixed bloods, in the widespread belief that moral and cultural background and poor educational ability is a product of biological inheritance, when in truth the social inheritance which we whites could so very easily change for them is [so] overwhelming that few of us would be likely to overcome it ourselves if we had such a really unfavourable start in life. ${ }^{72}$

For many years the media had reported on the social prejudice of settlers towards Aboriginal people. In July 1956, the Herald wrote that Aboriginal people were subjected to racial prejudice by their Anglo neighbours, with remarks such as 'Abos! Bloomin' no hopers ... They'll never be any real good' ${ }^{73}$

Police reports submitted to the Inquiry also noted the existence of racism. Senior Constable Haag, of Mooroopna, wrote in his report that the local Aboriginal people were made 'to feel their position racially' and that Aboriginal people were often exploited by local employers. ${ }^{74}$ During the same period, Police Superintendent Donnelly, in charge of the Shepparton-Mooroopna area, stated that 'white people do not, except in the case of degenerates, associate with colored people. Any whites associating with colored people are generally regarded as being of poor class and are ostracised by other whites ... [Aboriginal people] are constantly made to feel their inferiority'. ${ }^{75}$ McLean did not display a comprehension of, or choose to highlight the harmful effect of racism on Aboriginal people and their ability to blend into the dominant community.

69. Jackomos and Fowell 1991: 18.

70. McLean Report: 11.

71. The Age, 14 April 1956.

72. Margaret and Percy Holmes, letter submitted to the McLean Inquiry, 23 February 1956, NAA: B408, 1956/9.

73. Herald, 5 July 1956.

74. Senior Constable Haag, Police Report submitted to the McLean Inquiry, 23 March 1956, NAA: B408, 1956/4.

75. Police Superintendent Donnelly, Police Report submitted to the McLean Inquiry, 27 March 1956, NAA: B408, 1956/4. 
McLean's reluctance to apportion blame to Anglo-Australians' prejudice reinforced the idea that Aboriginal people were the cause of social discord in Australian society. Therefore assimilationists believed that efforts to socially re-engineer Aboriginal people to reflect their Anglo-Australian counterparts, through assimilation programs, would result in the appeasement of racial tension.

McLean's recommendation to sell large sections of the Lake Tyers Aboriginal station, on 4000 acres near Lakes Entrance, intensified the arguments for the Victorian government to officially adopt assimilation. McLean was directed to investigate whether Victoria's last remaining Aboriginal reserve, Lake Tyers, should continue to operate and if so, under what system of management. In June 1956 McLean visited the reserve and spoke with past and present management officials, Major Ronald Glen and Mr Len Rule respectively. He deemed their information 'specially informative'. ${ }^{76}$ McLean described the reserve as an 'unsatisfactory' institution which largely catered for an 'indolent' group of Aboriginal people. He exonerated the reserve management for the sub-standard living conditions, blaming a lack of government funding and Aboriginal people's innate indolence for the conditions. ${ }^{77}$ McLean's notes indicate that he inspected local fringe camps and spoke to Aboriginal fringe-dwellers, but no evidence exists that he interviewed any of the Lake Tyers residents. His findings on Lake Tyers appear to be based on information given by Glen and Rule. Although the Bolte government had only been in power for a few months, McLean's criticism of past Labor and Liberal governments indicated that he was not merely a puppet for this regime. If he had wished to simply pander to the Victorian government he could have omitted this statement or blamed the previous Labor administration for failing to adequately care for disadvantaged Victorians.

From the 1940s, the Lake Tyers community had publicly criticised its management. In March 1947 the Age reported that people were leaving Lake Tyers because the standard of living was 'atrocious' ${ }^{78}$ An article in the Herald emphasised this discontent, stating that many Aboriginal people preferred to live in squalid humpies than return to the oppressive management and life on the government station. ${ }^{79}$ At a public meeting held in Box Hill Town Hall, in February 1948, the Anglo-Australian philanthropist Cora Gilsenan, declared that many Aboriginal people refused to return to Lake Tyers because they were terrified of the management. ${ }^{80}$ McLean did not acknowledge these complaints made by Aboriginal people and campaigners about Lake Tyers. Instead he looked at the reserve in economic terms. He recommended that 3800 acres of the settlement be sold and the remnant of the reserve land be used for the care of sick, aged or infirm Aboriginal people. The remaining Aboriginal people should be encouraged to settle in the mainstream community where their assimilation could be facilitated. ${ }^{81}$

McLean's final term of reference was to determine whether a system of administration for Aboriginal people should be maintained. McLean was directed to classify

\footnotetext{
McLean Report: 4.

McLean Report: 13-14

The Age, 1 March 1947.

79. Herald, 6 March 1947.

80. Sun, 19 February 1948.

81. McLean Report: 14-15.
} 
which people should be considered as Aboriginal; to determine the principles upon which the system should be based and to decide upon requisite legislative and administrative provisions which would enable a system to operate in the 'best interests of both the public and aboriginal people. ${ }^{82}$ In making his decision, McLean relied on information gathered from annual reports written by authorities charged with the responsibility of Aboriginal welfare in all mainland states, excluding New South Wales. In regard to New South Wales, he sent the Secretary of the Victorian Board for the Protection of Aborigines, Mr N Garnet, to investigate the administration system used by that State's Welfare Board ${ }^{83}$ McLean also interviewed the Chairman of the New South Wales Board, Mr Buttsworth, to gauge his views on the operation of the State's new assimilationist administration. ${ }^{84}$

McLean concluded that if assimilation was to be achieved, a new system of administration was imperative. The proposed Victorian model of administration closely reflected its New South Wales counterpart. He recommended that an Aborigines Welfare Board be established and that it should be a body corporate, with all land set aside for Aboriginal purposes to be vested in it. ${ }^{85}$ He considered that the Board should consist of at least nine members, including the Superintendent of Aboriginal Welfare; nominees of the Ministers responsible for Housing, Education and Health; a specialist in the field of anthropology and/or sociology and one Aborigine. All members, except for the Chairman, were to be appointed by the Governor-in-Council. ${ }^{86}$ In order to maximise the Board's effectiveness, McLean insisted that legislation be introduced to enable the Board to bring under its control any person with an 'admixture' of Aboriginal blood. This action served to broaden State control and surveillance of all Aboriginal people in Victoria, rather than the few residents at Lake Tyers. McLean argued that legislative reform was imperative for the enforcement of assimilation programs and that an Aborigines Welfare Act needed to be passed to replace the existing 1928 Act. $^{87}$ The recommendations proposed by McLean were by no means revolutionary. In the 1940s and 1950s, the federal and some state governments established Aboriginal Welfare authorities. These were responsible for the implementation of programs designed to assimilate Aboriginal people into mainstream Australian society. McLean appeared to follow the national trend.

The McLean Report's positive reception, in both government and press circles, illustrated the desire of the politicians and the general public for the introduction of an assimilation policy in Victoria. Most press accounts praised McLean for compiling a 'first-class report'. ${ }^{88}$ The Labor member for Albert Park, Patrick Sutton, described the report as 'the most valuable documentary ever compiled in Victoria on the broad social,

\footnotetext{
82. McLean Report: 14-15.

83. McLean Report: 16. The 'Aboriginal problem' in New South Wales was similar to that in Victoria in that 'mixed descent' Aboriginal people comprised the majority of the State's Aboriginal population. This fact attributed to the greater value which McLean gave to the information gained from New South Wales sources.

84. McLean Report: 16.

85. McLean Report: 15-21.

86. McLean Report: 16 \& 19.

87. McLean Report: 19-20.

88. Bulletin, 13 February 1957.
} 
cultural, anthropological and economic aspects of the lives of a segment of the population whose treatment by white people forms a murky chapter in the history of Victorian and Australian colonization'. ${ }^{89}$ Sentiments such as this revealed the aspirations of many people to redress the harsh social conditions under which many Aboriginal people lived. Twenty-four hours after its presentation to parliament, the Victorian government announced that the recommendations proposed by McLean would be embodied in new legislation. ${ }^{90}$ This swift announcement seems to indicate that the Victorian government was confident about the outcomes of the inquiry.

Although widespread support existed for the assimilation philosophy of McLean's report, some parliamentarians criticised the detail. Sutton expressed some of the major concerns during the second reading stage of the parliamentary debates. $\mathrm{He}$ emphasised the exclusion of an exact definition of Aboriginality; the sale of vast tracts of land associated with the Lake Tyers Reserve; too many responsibilities associated with the Under Secretary's position on the new Board; too few Aboriginal representatives on the Board and the need for an Advisory Council to be attached to the Board. ${ }^{91}$ The main issue which dominated parliamentary debates was the fact that there was insufficient Aboriginal representation on the Aborigines Welfare Board. The Labor Party proposed that at least three Aboriginal people should be elected as members. Sutton stated that more Aboriginal representation would ensure that obstacles which hindered assimilation would be identified early. ${ }^{92}$ However, the government was steadfast in recommending that only one Aboriginal person be appointed. Most of the amendments proposed by the Labor opposition were not acted upon and the Aborigines Act 1957 was quickly passed. The only proposal in McLean's report not included in the new legislation was the sale of land at Lake Tyers. Both the government and opposition members agreed that any sale was unwise given the uncertainty of successful assimilation. McLean may have thought that this proposal would be popular amongst the Liberal Party members as the sale would have contributed to government revenue and would have minimised expenditure at the reserve.

Many campaigners for Aboriginal rights and welfare publicly criticised McLean's findings. Anna Vroland, an Anglo-Australian activist, was one of the first people to denounce the McLean report. Vroland had been an ardent campaigner for Aboriginal rights for over two decades. The main criticisms she levelled at the Inquiry were that it had been carried out by one person, that public evidence was not able to be given by interested parties, and that expert opinion from an anthropolgist and/or sociologist was not obtained. ${ }^{93}$ She also denounced McLean for failing to consult with Aboriginal people. Although he claimed to have consulted with Aboriginal leaders - Pastor Doug Nicholls and Shadrach James - there is no evidence or acknowledgment of their influence on his findings. Detailed submissions were made to the Inquiry by Aboriginal activist groups such as the Council for Aboriginal Rights (CAR), Victorian Aboriginal Group, and the Aborigines Advancement League. These submissions are amongst

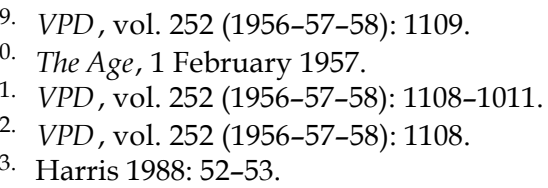


McLean's archival notes, with letters of acknowledgment, as well as requests for further information. Yet their contribution to McLean's Inquiry appears to be non-existent in his final report. CAR also condemned McLean for regarding Aboriginal people as a race and for his assertion that Aboriginal people were incapable of independently managing Lake Tyers. ${ }^{94}$ During the parliamentary debates over the proposed Aborigines Bill, Sutton raised the concerns of the protesters. He stated that comments made by these people were interesting, however he considered them to be somewhat erratic. ${ }^{95}$ Mr Mitchell, a Country Party member, was more severe when he branded all critics as 'communists' ${ }^{96}$ Although some critics, particularly some members of CAR, were supporters of communism, ${ }^{97}$ the majority of protests were voiced through non-partisan organisations. Even though opposition to McLean's report existed, it was largely futile, as public support for assimilation was so intense.

The McLean Inquiry could be regarded as a 'rubber stamp' for reformist legislation which the Liberal government wanted to introduce in the area of Aboriginal welfare in the late 1950s. In some respects, McLean's reputation as a conservative Anglophile ensured that the outcomes of the Inquiry could be pre-determined by the government. McLean's attitude was evident in the manner in which he denigrated Aboriginal culture and celebrated assimilation as the 'solution' to Victoria's 'Aboriginal problem'. However, McLean was not entirely manipulated by government influences. This was shown by his willingness to deviate from the government's definition of Aboriginality and his recommendation to sell land at Lake Tyers. Despite the narrow focus of the McLean Inquiry and the pre-emptive nature of his findings, the final report provided formal documentation concerning Aboriginal people in Victoria. Even though some of McLean's information was common knowledge amongst many Aboriginal welfare and political organisations, this was the first comprehensive, 'official' government study outlining the situation of Victorian Aboriginal people in the 1950s. McLean both legitimised assimilation and contributed original ideas to Victoria's assimilationism.

\section{References}

\section{Primary sources}

The Age

Argus

The Bulletin

Bulletin (Council for Aboriginal Rights)

The Herald

The Sun

The Sun News Pictorial

National Archives of Australia, CRS B408, Records Relating to the McLean Inquiry into the Aborigines Act 1928 and Regulations and Orders made thereunder.

94. Council for Aboriginal Rights, Bulletin, no. 10 (April 1957).

95. VPD, vol. 252 (1956-57-58): 1008.

96. $V P D$, vol. 252 (1956-57-58): 1013.

97. See Hulme 1992. 
Commonwealth of Australia, Parliamentary Debates, Canberra.

Victorian Parliamentary Debates, Melbourne.

Victorian Parliamentary Papers, Melbourne.

\section{Secondary sources}

Bate, Weston 1978, Lucky city: the first generation at Ballarat 1851-1901, Melbourne.

Boas, Philip 1972, 'The role of the Ministry of Aboriginal Affairs, Victoria' in L Lippman, (ed), Seminars 1971, Centre for Research into Aboriginal Affairs, Monash University, Clayton, Victoria: 21-35.

Broome, Richard 1980, 'Professional Aboriginal boxers in eastern Australia 1930-1979', Aboriginal History 4: 48-71.

_- 1994, Aboriginal Australians: black responses to white dominance 1788-1994, Allen \& Unwin, St Leonards, New South Wales.

— 1995, 'Victoria' in Ann McGrath, (ed), Contested ground: Australian Aborigines under the British Crown, Allen \& Unwin, St Leonards, New South Wales: 121-167.

Bropho, Robert 1980, Fringedweller, Alternative Publishing Co-operative with the assistance of the Aboriginal Arts Board, Australia Council, Chippendale, New South Wales.

Brown, Nicholas 1995, Governing prosperity: social change and social analysis in Australia in the 1950s, Cambridge University Press, Cambridge.

Christie, MF 1979, Aborigines in Colonial Victoria 1835-1836, Sydney University Press, Sydney.

Collmann, J 1988, Fringe-dwellers and welfare: the Aboriginal response to bureaucracy, University of Queensland Press, St. Lucia, Queensland.

Cowlishaw, Gillian 1999, Rednecks, eggheads and blackfellas: a study of racial power and intimacy in Australia, Allen \& Unwin, St Leonards, New South Wales.

Cuthill, William n.d., 'Charles McLean C.B.E. 1889-1978: a biography', Unpublished Manuscript, in possession of William Cuthill, Melbourne.

Harris, Mark 1988, 'A ‘new deal' for Victorian Aborigines 1957-1968', M.A. thesis, History Department, Monash University, Clayton, Victoria.

Hasluck, Paul 1953, Native welfare in Australia: speeches and addresses, Paterson Brokenshaw, Perth.

_ 1988, Shades of darkness: Aboriginal affairs 1925-1965, Melbourne University Press, Carlton, Victoria.

Hulme, Vaughan 1992, ‘Working for; working with black protest: the Council for Aboriginal Rights 1951-1968', Honours thesis, History Department, La Trobe University, Melbourne.

Jackomos, Alick and Fowell, Derek 1991, Living Aboriginal history of Victoria: stories in the oral tradition, Cambridge University Press, Melbourne.

Landon, Carolyn and Tonkin, Daryl 1999, Jackson's Track: memoir of a Dreamtime place, Viking, Ringwood, Victoria.

Lyons, Gregory 1983, 'Official policy towards Victorian Aborigines, 1957-1974', Aboriginal History 7(1): 61-79. 
Markus, Andrew 1990, Governing savages, Allen \& Unwin, Sydney.

McGregor, Russell 1997, Imagined destinies: Aboriginal Australians and the doomed race theory, 1880-1939, Melbourne University Press, Carlton, Victoria.

Rowley, CD 1971, Outcasts in white Australia: Aboriginal policy and practice, vol. 2, Australian National University Press, Canberra.

Samson, Basil 1980, The camp at Wallaby Cross: Aboriginal fringe dwellers in Darwin, Australian Institute of Aboriginal Studies, Canberra.

Strehlow, TGH 1964, Assimilation problems: the Aboriginal viewpoint, Aborigines Advancement League Inc. of South Australia, Adelaide.

Taffe, Susan 1995, 'Australian diplomacy in a policy vacuum: government and Aboriginal affairs, 1961-1962', Aboriginal History 19(2): 154-172.

Tatz, C 1990, 'Aboriginal violence: a return to pessimism', Australian Journal of Social Issues, 25(4): 245-260.

Tonkinson, Myrna 1990, 'Is it in the blood? Australian Aboriginal identity' in Cultural identity and ethnicity in the Pacific, J Linnekin and L Poyer, (eds), University of Hawaii Press, Hawaii: 191-218. 